\title{
THE POTENTIAL RURAL RELIGIOUS TOURISM OF SOUTH CRISANA REGION FROM ROMANIA AND THE ECONOMIC IMPLICATIONS OF RURAL TOURISM
}

\author{
BARBU, I[onel]
}

\begin{abstract}
In this paper we will present an analysis on the potential of rural tourism in the south region Crisana.From an administrative stand point, the South part of the Crisana region is bordered by Bihor in the north, the Alba, county in the East, the Timis county and the county of Hunedoara in the south and the border with Hungary in the West.

Impact or implications of rural tourism refers to tourist industry effects on the local community, the area and the tourists. The impact of tourism can be positive or negative, depending on the effect they induce on the community or area. To study the impact of rural tourism, as emphasized in the literature, we have to analyze all government and local administration, entrepreneurs, residents and tourists.

We want to present the main economic implications of rural tourism on the government and local administration, entrepreneurs, residents and tourists.
\end{abstract}

Keywords: rural religious tourism, economic implications, Crisana, touristic potential

\section{INTRODUCTION}

The varied relief, which decreases from east to west, the existence of a continental temperate climate with many areas of shelter (Halmagiu depressions, Baita, Almas-Gurahont, Moneasa, Mures river lane), important surfaces of forested areas, about $25-30 \%$ of the surface of this area, the existence of mieral water sources, a rich hydrographic network, dominated by the two arteries Crisul Alb and Mures and also a karst landscape, provides sufficient conditions for practicing a quality rural tourism.

There is the view that the leisure, holidays or vacations in the countryside and visits to places of worship which is practiced the so-called religious rural tourism [1].

Our opinion is that according to the considerations for which the visits to the places or worship are made we can distinguish the cultural rural tourism when it aims to see the architecture or painting of these places, or the religious rural tourism when pilgrimages are made when there are religious holidays or when visiting those targets for prayer at certain miracle icons or other symbols that have entered the minds of believers as beneficial to human health.

In a study [2] done on the impact of rural tourism in North Carolina, there were found differences between the perceptions of the four groups involved:

- between entrepreneurs and government officials;

- between residents and government officials;

- between residents and entrepreneurs;

- between locals and tourists.

These differences in perceptions of those involved on the impact of tourism can generate conflicts between stakeholder groups. These conflicts are based on individual interests and different perceptions of overall costs and benefits of tourism activities. To effectively reduce conflicts, it is necessary that the attitudes and perceptions of stakeholders are identified, analyzed, understood and ultimately, through mediation and negotiation, to make proposals to eliminate or reduce conflicts.

Government officials recorded positive results because tourism development leads to improved quality of life in the communities, improve the appearance of towns and develops the local economy. Entrepreneurs are satisfied because the infrastructure investment can bring them profit, but may occur and pressure on employment, if the development is too consistent or uncontrolled.

Tourists are widely satisfied for the conditions created so that they could spend the holidays or vacations as low prices in exchange for quality and diversified services. Instead, residents, although they are thankful for the positive socio-economic impact, taking into account the increased taxes, increased crime, public insecurity and not least environmental damage.

Starting from the idea that rural tourism should be a complementary activity to agriculture, as a result of research conducted [3] it was found that farm interest to tourists only on a very small extent. However there is a strong entrepreneur benefits from farm working. The same authors argue that "a farm producing goods, agricultural and tourism services appear to use inputs more efficiently than firms that do not develop tourism near the farm".

The same view is shared by us since an "aggregate" activity is more profitable than separate activities due to lower supply costs, sales and transportation.

Thus, although it seems that separate accommodation areas are separated from the agriculture, a farmer will continue to benefit from an agricultural farm.

Our opinion is that the authors Alize Fleischer, and A. Tchetchik captured this very well because a farmer who made an "integrated" farm with guesthouse can capitalize more efficiently and faster the products made so that it will not be a problem selling products produced on the farm especially with today selling products became as or more difficult than production.

From the literature we not found studies that show rural tourism in the region Crisana. When these studies were made were related to certain counties of this region of Romania. Historical region Crisana includes the 
counties of Arad, Bihor, northern of Hunedoara and eastern of Salaj and an important part of eastern Hungary, but in our study we will refer only to the Romanian part.

For Arad county few studies have been conducted on the evolution of rural tourism and we concluded that this area has great potential and should be exploited [4]

\section{THE CRISANA REGION}

In this chapter we will present some data about the area Crisana:

-favorable geographical position, the gateway into the country from the West, several border crossing points, both road and rail;

-varied landscape and beautiful natural landscape with potential for practicing various forms of tourism the mountains about $25 \%, 35 \%$ hills and $40 \%$ plains;

-particularly karst topography (over 6000 caves from which dozens are arranged and are great attractions for both tourism and caving);

-large number of natural reserves and protected areas (Arad county has 17 and 2 of them are natural monuments, Bihor county has 61 of which 16 are natural monuments, Hunedoara county has 12 of which 2 are natural monuments, and Salaj county has 4 . In total there are 94 reservations of which 20 are natural monuments);

-diversity and the relatively high number of natural attractions and antropics: about 1100, of which about 550 in villages (in Arad 414 objectives of which about 200 in rural areas, in Bihor 435 of which about 200 in rural areas, in Hunedoara 140 of which about 100 in rural areas and in Salaj 135 of which 60 in rural areas), historical and architectural monuments, archaeological sites, fortresses, castles, places of worship (churches, wooden monasteries century. XVI-XVIII);

-mountain paths in the Zarand Mountains, CodruMoma, Bihor, practicable and for cycling, European path of long distance E7 which is crossing the Arad county from west to east;

-rich network of rivers and hot or mineral water sources with potential for geothermal drilling, famous spas (Baile Felix, 1 Mai, Moneasa Geoagiu Bai, Lipova, Stana de Vale);

\section{RURAL RELIGIOUS TOURISM OF SOUTH CRIŞANA REGION}

The diversity of the ethnic communities that live along the Romanian community like Hungarians, Germans, Serbs, Slovaks, Bulgarians, Jews, Gypsies is reflected in the diversity of the religious forms: Orthodox, Roman Catholic, Reformed, EvangelicalLutheran, evangelical, Greek Catholic, Mosaic.

Most common places of worship with historical value are[5,6,7,8,9,10,11]: Orthodox monastery Hodos Bodrog, Felnac village, one of the oldest monasteries in Romania, was recognized in 1177, dedicated to "Virgin's entrance into the Church" Serbian Orthodox monastery Bezdin, in the village Munari, Secusigiu village, St. Mary's Roman Catholic Cathedral in Radna (1756), built on the site of a former church whose cornerstone was laid in 1520 and destroyed by the Turks on the 1551, dedicated to "St. Mary's. Near the cathedral there is the Franciscan
Monastery(1747); Lipova Orthodox Church, the religious painting dated in the fifteenth century, rebuilt in Baroque style in the eighteenth century, Monastery and Hermitage Feredeu, Siria, with the healing source from which it derives its name "Saint George", the Catholic Church in Vinga built in 1892 , in Gothic style, built by the Bulgarian community in Vinga, Hermitage Rosia, Dieci village, dedicated to "St. Archangels Michael and Gabriel" Crisan Monastery in the Crisan village, dedicated to "Birth of the Virgin"; Hermitage Criscior, in the Criscior village named "The Saint Trinity", wooden Churches from sec. XVIII-XIX: Obarsia, Corbesti, Rosia, Petris, Poiana[6].

Within the county of Hunedoara there are many churches such as: Wooden Church "Saint Nicholas" in Salistioara village, built in 1830, Wooden Church "Buna Vestire" in the village Dealu Mare, built in 1868, wooden church "St. John Gura de Aur" in the Bulzestii de Sus village, built in 1853, wooden Church "Buna Vestire" in the village Tomnatec built in the eighteenth century, wooden church "Inaltarea Domnului" in the Salatruc village, built in 1830, wooden church "Buna Vestire" in the Grosuri village, built in 1855, Church "Saint Nicholas" Ribita village, built in 1417, Church "Adormirea Maicii Domnului" in the Crisan village, built between 1844 to 1852, wooden Church "Adormirea Maicii Domnului" in the Dumbrava de Jos village, a nineteenth-century building, wooden church "Nasterea Domnului" in the Dumbrava de Sus village, built in 1844, wooden church "Sfanta Cuvioasa Parascheva" Ribicioara village, built in 1763, church "Saint Nicholas" Uibaresti village, a nineteenth-century building, wooden church "Buna Vestire" in the village Hartagani, an eighteenth-century building, wooden church "St. Nicholas" in the village of Cave; Orthodox Church "Buna Vestire" in the Baita village, Orthodox Church "Buna Vestire" in the village Trestia, Roman-Catholic church in Baita, Monastery "Acoperemântul Maicii Domnului" from Baita, Ormindea Orthodox Church, Church "Saint Nicholas" in the village of Barsau, a sixteenth-century building, church "St. Demetrius" in the Harau village, built in the eighteenth century, church "Cuvioasa Parascheva" in the Chimindia village, built in the sixteenth century.

\section{ECONOMIC IMPLICATIONS}

Economic implications of tourism, shows the effect of all tourist activities and tourist industry in general, upon the local, national or even global economic status.

Looking at the share of tourism in the whole world economy [12] we find that it represents almost $10 \%$ of all investments and that means that in the world every 11 jobs there is a job in tourism and it represents about 5\% of world gross domestic product.

The economic implications can be positive or negative. The most ,visible” positive implications would be generating a profit for the local community and tourist businesses, creating jobs and raising living standards and the negative economic implications can be felt by the locals refer to fees for maintenance and supply tourist facilities.

Rural tourism, like any economic activity, is based on a certain economic efficiency, which is its purpose too, 
but not at the level of the very optimistic forecast, which does not take into account the fact that the activity recorded good results only in summer and winter, and do not take account of the complementarity of this peasant activities. Rural tourism should not be regarded as a closed system in which all the tourist needs and shall provide the owner household occurs only pension or locality. Products or services outside the household and village that tourist needs are very diverse and involves significant costs for their purchase. So tourism has economic implications not only in the place or area under discussion or analysis.

Precisely for this, it is necessary to establish situations accurately highlighting the value of inputs, source of supply and quality of inputs and outputs value for tourism activities. These inputs and outputs could put in a new conception of economic efficiency of rural tourism and could see the connection with other branches of the economy, from transportation to food, textile, engineering and not least IT industry.

In current conditions, potential tourist and recreational resources proved to be equally or even more important than material resources, because the supply of tourist services generate an influx of monetary resources, expand the scope of employment and stimulate the development of several key sectors of the economy: construction, trade, catering, transport, communications, agriculture and others.

In our opinion, for a higher value of agricultural products, rural tourism is required to be a complementary farm economic activity and not an alternation or a substitute thereof.

This form of economic activity provides people with low incomes who can not afford expensive holidays, can rest, and does not require huge investments for the administration and contractors for general infrastructure facilities and tourist facilities or other facilities of profile.

For development of this sector is necessary, however, a consistenly involvement, coherent and strategic from the entrepreneurs, business people [13]. The results clearly demonstrate the importance of community approach to tourism development and rural tourism development and entrepreneurship can not function without the participation and cooperation of business people directly and indirectly involved in tourism.

There are situations when such activity does not lead to welfare of the community only in a small manner because there may appear tourism indusrty leaders that are only interested in opportunities to capitalize on tourism for their accumulation and gain the limited comunity resources for their needs. Thus exploitation and wasted potential is incomplete, and community expectations to obtain significant benefits remain unfulfilled .

According to some economic experts [14], the aggregate value of goods and services generated by tourism related sectors, worldwide travel services exceeds the cost by a factor of about 2.5. By some estimates, according to the same sources, each tourist offer between 10 and 20 jobs in the sphere of tourism such as hotels and guesthouses, restaurants, souvenir manufacturing or leisure or business.
Tourism is undoubtedly one of the most important forces shaping our economic world [15]. From an economic perspective, tourism is of increasing importance for more and more nations are recognized as "the most important export sector" and a leading provider of employment work. Especially in developing countries the tourism is stimulated as a reliablle economic development that does not harm as extractive industries do, and can be used to generate revenue for other development activities.

Tourism development is required in rural areas, for economic purposes, and bi-univocal implications socially. Thus, rural tourism contributes to the economic life of the village by following [16]:

- the village is long-term development perspective, closely linked to agriculture, infrastructure and curdling a climate, a business environment;

- it is possible to become a support for new businesses and new jobs (pension manager, receptionist, maid, bartender, cook, waiter, plumber, guide, fireman, etc.) to determine local development;

- to encourage local activities, especially crafts, but also can cause the development of a specific trade and creating new jobs (pottery, blacksmithing, milling, weaving wattle);

- it stimulates the growth of revenues for population in rural settlements generated by exploiting local resources, organic food products for consumption for the tourists or even for sale to them

- lead to an increase in quality of life in rural areas.

Tourism development affects the improvement of the infrastructure and architectural restoration of historic monuments and promote environmental conservation. This is why tourism should be considered an important factor in social and economic development of the country, some regions, individual areas and rural areas in particular.

The economic impact of tourism is dependent of the economical level of the area. For example, in southern Poland, [17] the largest concentration of private firms in rural areas was observed in Bielsko Biala region, with 51 companies per 1,000 inhabitants of the rural population. Economic development can be found also in areas like Krakow and Nowy Sacz. These three regions have good conditions for tourism development due to the relatively high economic level (Bielsko-Biala and Cracow) and natural conditions for tourism as the border between Poland and Slovakia (Bielsko-Biala and Nowy Sacz).

Most speciality literature deals with the rural tourism in Romania also. For example in the Apuseni Mountains is considered at this stage only trade and tourism might be the best way for investment [18]. This requires the construction of hotels and hostels in major cities in the area of services in major intersections, or development activities campsites near existing restaurants and inns. Apuseni Mountains has a good potential to attract visitors, especially since the area is relatively close to Central Europe, which is very convenient for tourists from Austria and Hungary.

The northern part of the mountains is accessible from the future highway Oradea-Cluj-Brasov and the other access road starts from Stei and goes down the Aries Valley to Turda. 
Today, in many countries, the tourism industry fall within the priorities of the state, which is why there are many large projects of national and international programs and providing incentives for development of the sector: tax advantages, simplification of visa and border control customs, and creating favorable conditions for investment in economic areas with potential.

The economic implications of rural tourism in the region Crisana were presented in a series of papers published in various specialized conferences [19].

\section{FUTURE RESEARCH}

In future research tried to do an analysis of rural tourism activity in the region Crisana for the period 1990-2012. As expected, after 1990, rural tourism has grown increasingly more. In most rural tourist potential areas appeared much pension offers tourists an alternative to classic tourism. Until 2008, year of installation economic crisis and the number of pensions and places have increased year by year. Only after 2009 appears stagnation following economic crisis.

More acceptable prices of services in rural guesthouses and conditions offered by rural people will continue to represent the main reasons why many tourists will be targeted for such services at the expense of the great classic and famous tourism resorts.

In future research we will analyze the evolution of the main indicators by which we can characterize the rural tourism activity in the region Crişana namely: number of accommodation units in rural areas; number of rooms; number of arrivals in accommodation; number of overnight stays; length of stay.

Also the period after 2008 will be interesting to see the economic and financial crisis has influenced the work of rural tourism in this region of Romania.

Based on research that will make we want to make some proposals that will lead to much better control over the activity of economic agents to increase the visibility of the places that shows great tourism potential therefore to increase the demand for tourist services in rural areas.

\section{CONCLUSIONS}

Theoretically, there is no rural settlement that can not provide at least one brand, to raise the interest from tourists. The precondition is that the mark is genuine, original, and the efforts to make the mark known, have to make possible the recognition and and afterwards the recognition and searching after it. Extrapolating this to the romanian village, it is obvious that at the level of the majority of rural settlements, their defining hallmark is multiple: landscape quality and warmth of the inhabitants, technical art and folk, traditional occupations, costumes, customs, cuisine and resources place. The key is to perpetuate this diversity, but also to highlight the elements that give a touch of local specificity and can therefore become branded products, which can provide recognition in the tourist circuit.

Given the economic, psychological, objective and subjective reasons, for which investment in rural tourism is justified and is promising profit and welfare, allow us to make up the next tourist Decalogue that a tourist would like to spend a holiday or a vacation in rural areas:

1. Because often, you have the best feeling in the nature, at a real and peaceful guesthouse;

2. Because often you feel better surrounded by hospitable people;

3. Because there, in nature, you regain your roots;

4. Because there, in the village, we regain ancestral customs and tradition;

5. Because there, in nature, you regain peace and relaxation;

6. Because there you forget everyday problems and stress;

7. Because there you find new friends, to which you will return always with great love;

8. Because there you can avoid crowded areas, very heavily visited;

9. Because there are much more possibilities of spending the leisure time are completely different from the places offered by mass tourism, traditional

10. Because there could be an alternative for reducing unemployment and raising living standards of residents.

\section{REFERENCES}

[1] Olah Gh., Barbu I. - Rural tourism in Romania, news and views Theoretical and Practical Approaches in Economics, Editura Universitatii Aurel Vlaicu Arad, 2010, pag. 348-357

[2] Byrd E., Bosley Holly, Dronberger Meghan - Comparisons of stakeholder perceptions of tourism impacts in rural eastern North Carolina - Tourism Management, nr.30, 2009, pag. 693-703

[3] Fleischer Aliza, Tchetchik A. - Does rural tourism benefit from agriculture? - Tourism Management, nr. 26, 2005, pag. 493-501

[4] Barbu I. - Analiza evoluţiei turismului în judeţul Arad - Lucrările sesiunii de comunicări ştiinţifice a doctoranzilor în economie, Ediţia a - II-a, Oradea, 23 noiembrie 2011

[5] *** (2012) http://www.beius.ro, accessed on 14.11.2011

[6] *** (2012) http://www.cjarad.ro, accessed on 18.11.2011

[7] *** (2012) http://www.padis.info, accessed on 19.11.2011

[8] *** (2012) http://www.padureacraiului.dap.ro, accessed on 18.11.2011

[9] *** (2012) http://www.parcapuseni.ro, accessed on 18.11.2011

[10] $* * *$ (2012) http://www.turismbihor.info, accessed on 10.11.2011

[11] *** (2012) http://www.virtualarad.net, accessed on 17.11.2011

[12] Barlybaev A., Akhmetov V.Y., Nasyrov G.M. - Tourism as a Factor of Rural Economy Diversification, Studies on Russian Economic Development, No. 6, Vol. 20, 2009, pag. 639-643

[13] Wilson Suzanne, Fesenmaier D.R., Fesenmaier Julie, Vanes J. Factors for Success in Rural, Tourism Development Journal of Travel Research, Volume 40, nr 2, November 2001, pag 132-138

[14] Higgins-Desbiolles Freya - More than an "industry": The forgotten power of tourism as a social force, Tourism Management, nr. 27, 2006, pag. 1192-1208

[15] Higgins-Desbiolles Freya - More than an "industry": The forgotten power of tourism as a social force, Tourism Management, nr. 27, 2006, pag. 1192-1208

[16] Ionaşcu Gh. - Satul şi dezvoltarea rurală, Revista Calitatea Vieţii, nr.3-4, 1995

[17] Gorz B., Kurek W. - Variations in technical infrastructure and private economic activity in the rural areas of Southern Poland, GeoJournal, nr. 46, 1999, pag. 231-242

[18] Abrudan I., Turnock D. - A rural development strategy for the Apuseni Mountains, Romania, GeoJournal, nr. 46, 1999, pag. 319-336

[19] Barbu I., Barbu S. - Rural tourism - economic implications International Scientific Conference, Ecotrend, 2011, 8th Edition, 25-26 november, Târgu Jiu 